\title{
Mycological Investigation of Bottled Water Dispensers in Healthcare Facilities
}

\author{
Zsófia Tischner ${ }^{1,2, *, \dagger}{ }^{\dagger}$ Rózsa Sebók ${ }^{1, *,+}$, László Kredics ${ }^{3}{ }^{\oplus}$, Henrietta Allaga ${ }^{3}$, Márta Vargha ${ }^{2}$, Ágnes Sebestyén ${ }^{2}$, \\ Csaba Dobolyi ${ }^{1}$, Balázs Kriszt ${ }^{1}$ and Donát Magyar ${ }^{2}$
}

1 Department of Environmental Safety, Institute of Aquaculture and Environmental Safety, Hungarian University of Agriculture and Life Sciences, H-2100 Gödöllő, Hungary; dobolyi.csaba@mkk.szie.hu (C.D.); kriszt.balazs@szie.hu (B.K.)

2 National Public Health Center, H-1097 Budapest, Hungary; vargha.marta@nnk.gov.hu (M.V.); sebestyen.agnes@nnk.gov.hu (Á.S.); magyar.donat@gmail.com (D.M.)

3 Department of Microbiology, Faculty of Science and Informatics, University of Szeged, H-6726 Szeged, Hungary; kredics@bio.u-szeged.hu (L.K.); henrietta.allaga@gmail.com (H.A.)

* Correspondence: zsofi.tischner@gmail.com (Z.T.); sebok.rozsa.eszter@szie.hu (R.S.)

+ These authors are contributed equally to the work.

Citation: Tischner, Z.; Sebők, R.; Kredics, L.; Allaga, H.; Vargha, M.; Sebestyén, Á.; Dobolyi, C.; Kriszt, B.; Magyar, D. Mycological Investigation of Bottled Water Dispensers in Healthcare Facilities. Pathogens 2021, 10, 871. https://doi.org/10.3390/ pathogens 10070871

Received: 21 May 2021

Accepted: 7 July 2021

Published: 10 July 2021

Publisher's Note: MDPI stays neutral with regard to jurisdictional claims in published maps and institutional affiliations.

Copyright: (c) 2021 by the authors. Licensee MDPI, Basel, Switzerland. This article is an open access article distributed under the terms and conditions of the Creative Commons Attribution (CC BY) license (https:/ / creativecommons.org/licenses/by/ $4.0 /)$.

\begin{abstract}
The usage of bottled water dispensers (BWDs) has spread worldwide. Despite their popularity, few studies have dealt with their microbial contaminants, and little attention is given to their fungal contamination. To our knowledge this is the first mycological study of BWDs in Europe. 36 devices have been examined in Budapest, Hungary. Despite of the strictly regulated water hygiene system in Hungary, molds and yeasts were detected in $86.8 \%$ of the samples, $56.76 \%$ were highly contaminated. Elevated heterotrophic plate counts were also observed in all samples compared to that of Hungarian drinking water. As all physical and chemical water quality characteristics have met the relevant national and European parametric values and neither totally explained the results of microbial counts, the effect of usage and maintenance habits of the devices were examined. Fungal concentrations were affected by the time elapsed since disinfection, days remaining until expiration of bottles, month of sampling and exposure to sunlight during storage. Microbes are able to proliferate in the bottled water and disperse inside the BWDs. Many of the detected fungal species (Sarocladium kiliense, Acremonium sclerotigenum/egyptiacum, Exophiala jeanselmei var. lecanii-corni, Exophiala equina, Meyerozyma guilliermondii, Cystobasidium slooffiae, Aspergillus jensenii, Bisifusarium biseptatum) are opportunistic pathogens for subpopulations of sensitive age groups and patients with immunodeficient conditions, including cystic fibrosis. Thus BWDs may pose a health risk to visitors of healthcare institutions, especially to patients with oral lesions in dental surgeries. The study draws attention to the need to investigate microbial contamination of these devices in other countries as well.
\end{abstract}

Keywords: water quality; water cooler; microorganisms; molds; bacteria; health risks

\section{Introduction}

Water is a necessary basis of life on earth and the provision of high-quality drinking water is essential. The WHO Drinking Water Quality Guidelines [1] recommend to consider microbiological, disinfection, chemical and radiological aspects, as well as organoleptic characteristics that affect the acceptance of water by consumers. The organization has collected and characterized the major factors posing microbiological risk, but did not set any guideline values, as the hazard, presented by the individual pathogens, varies by geographical area and population. Parametric values only apply to fecal indicators $(0 / 100 \mathrm{~mL})$. WHO also discusses opportunistic pathogenic organisms that may be present in the environment, but are only able to cause disease in certain vulnerable subpopulations (i.e., elderly, minors, pregnant women, people with burns and extensive injuries 
and immunocompromised patients). A list of pathogenic microorganisms which require monitoring is provided by the WHO Guidelines [1]. The European Union Drinking Water Directive sets parametric value for further bacteria, but not for fungi [2]. Direct detection of fungi by culture is required solely by Swedish legislation in Europe (limit value to $100 \mathrm{CFU} / 100 \mathrm{~mL}$ ) [3]. Some countries (such as Hungary and the Czech Republic) require microscopic investigation of drinking water and have set separate parametric values for groups of organisms: in Hungary, for fungi 0 individuals/L parametric value applies [4].

Relatively large amounts of biodegradable organic matter [1], warm or ambient temperature water [5] and low concentration of residual chlorine may lead to the proliferation of these organisms [1]. Bottled water might contain tap water, spring water or mineral water and consequently it is covered by various regulations in different countries, such as the drinking water legislation or food regulation. Most international bodies recommend using risk-based approaches for the production of bottled water, such as water safety planning or HACCP [6-8].

Fungal contamination of water contained in modern household devices, such as washing machines [9] and dishwashers [10,11] have attracted attention in the last decade, as they provide new habitats for microscopic fungi. Bottled water dispensers (BWDs, also known as water coolers, Figure 1) were rarely studied, the only study on them was carried out by Yamaguchi et al. [12] in residents and office buildings in Brazil. These devices are intensively used in public buildings, workplaces and in health institutions worldwide. However, in several studies fungal contaminations of bottled water were detected [3,12-16].

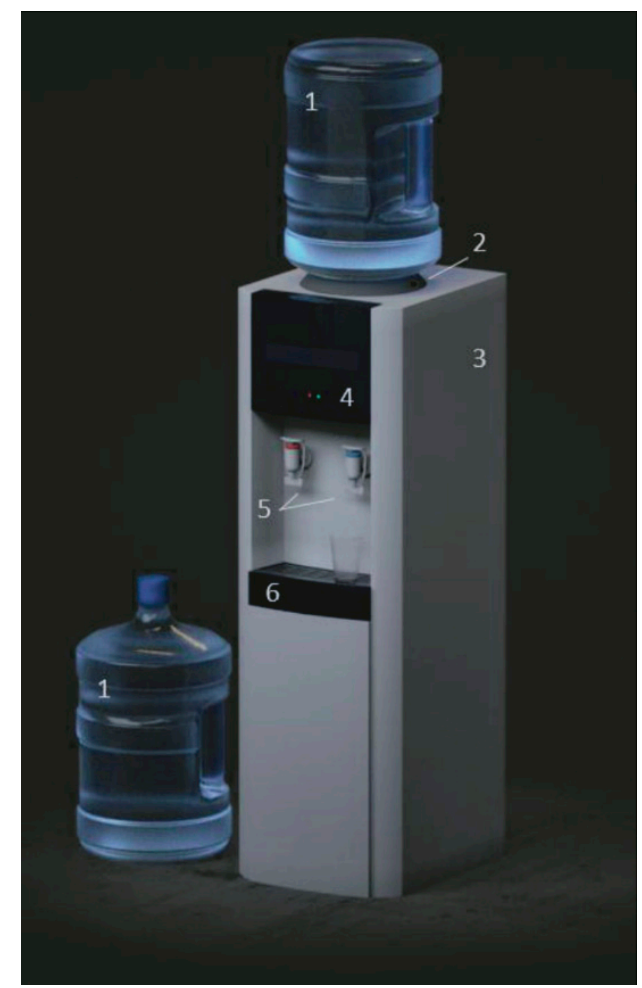

Figure 1. Assembly of bottled water dispensers. 1: bottle, 2: air filter, 3: hot and cold water tanks (inside of the device), 4: pipeline (inside of the device), 5: hot and cold taps, 6: drip tray. (3D graphics is courteously from Pavel Zosim).

In BWDs bottled water is supplied by a system of pipes, filters and taps. The simplest version of BWDs just cools the water, but often it is also able to heat it with a separate pipe system. Some devices provide carbonated water as well.

Previous studies demonstrated fungal contamination of drinking water and consequent health problems [3,17-20]. A recent study draws attention to the problem of 
pathogenic fungal contamination of tap water in hospitals [21]. Their results raise the question whether or not fungi can contaminate BWDs as well with a risk mostly to people using them in hospitals. The aim of the current research was to examine the mycological composition of BWDs operating in healthcare facilities (hospitals, pharmacies and dental clinics) in Budapest, Hungary.

\section{Results}

\subsection{Fungal Statistics}

The $56.76 \%$ of sampled water from BWDs was highly contaminated with fungi ( $>6 \mathrm{CFU} / \mathrm{mL}$ ). High concentration of filamentous fungi and yeasts was detected in $51.35 \%$ and $29.73 \%$ of the water from the devices, respectively. The most important relationships of the total fungal counts are the $\mathrm{pH}$, time since the last maintenance or disinfection and the temperature of water. Significance, correlation coefficients and components of total fungal values responsible for the relationship are listed in Table 1.

Table 1. Significant Pearson correlations between concentration of fungi and the parameters of water derived from BWDs.

\begin{tabular}{|c|c|c|c|c|}
\hline \multicolumn{5}{|c|}{ Pearson Correlation with Benjamini-Hochberg Correction } \\
\hline Parameter A & Parameter B [CFU/100 mL] & $p$ & $\mathbf{R}$ & Corrected $p$ \\
\hline \multirow{3}{*}{$\mathrm{pH}$} & Total Fungi ${ }^{a}$ & 0.0005 & 0.41 & 0.007 \\
\hline & * Yeasts ${ }^{\text {a }}$ & 0.0054 & 0.33 & 0.0252 \\
\hline & ${ }^{*}$ Filamentous Fungi ${ }^{\text {a }}$ & 0.02 & 0.28 & 0.04 \\
\hline \multirow{2}{*}{$\begin{array}{l}\text { Time since the last disinfection } \\
\text { or maintenance (days) }\end{array}$} & Total Fungi ${ }^{a}$ & 0.0064 & 0.62 & 0.0448 \\
\hline & ${ }^{*}$ Filamentous Fungi ${ }^{\text {a }}$ & 0.0056 & 0.62 & 0.0196 \\
\hline \multirow{2}{*}{ Temperature of water $\left[{ }^{\circ} \mathrm{C}\right]$} & Total Fungi ${ }^{a}$ & 0.0079 & -0.32 & 0.0369 \\
\hline & ${ }^{*}$ Filamentous Fungi ${ }^{\text {a }}$ & 0.0086 & -0.32 & 0.0241 \\
\hline
\end{tabular}

a: logarithmized data. ${ }^{*}$ : subcomponent variables contributing to the mean variable (Total Fungi).

Filamentous fungal counts obviously correlated with the number of yeasts in water samples, furthermore, with the filamentous fungal results of swab samples collected from the taps of BWDs. Expiration of the bottles (Figure S1), last maintenance or disinfection, TOC, month of sampling (Figure S2), exposure to sun and additional parameters, as listed in Table S1 also have been significantly related.

Number of yeasts correlated with nitrite ion concentration and the ordered quantity of the bottles was also a significant parameter, as shown in Table S2 containing the significant relationships of yeast counts of water samples.

The significant correlations of swab samples collected from drip trays are included in Table S3. Volume flow (Figure S3), detectable nitrite ion concentration of water, the exposure of bottles to sun during storage and presence of pseudo hardness in water had a significant effect on filamentous fungi. Yeast counts were affected by the site of operation of the device (i.e., on corridor or not) and by the extra disinfection by personnel besides the obligatory one during maintenance.

The total fungal counts of swab samples from taps significantly differed between the devices of two manufacturers (of the total 9 manufacturers) (Table S4). Alkalinity had the main effect on yeast counts.

In the water and swab samples a total of 81 fungal isolates were identified, respectively. Fungal taxa found in the samples are listed in Table 2. 
Table 2. Fungal species detected in water and swab samples ( $>4$ morphologically identical CFU) collected from bottled water dispensers in medical institutions.

\begin{tabular}{|c|c|c|c|c|c|c|c|}
\hline Identification & ID & Type & $\begin{array}{c}\text { Identification } \\
\text { Type }\end{array}$ & \multicolumn{2}{|c|}{$\begin{array}{c}\text { GenBank Accession } \\
\text { Number of: }\end{array}$} & $\begin{array}{l}\text { Relative } \\
\text { Frequency in } \\
\text { the Sample }\end{array}$ & Reference \\
\hline Acremonium egyptiacum & B2131C & cold water & Molecular & MT320780 & - & 0.27 & $\begin{array}{l}\text { [22] Perdomo et al., } \\
2011 \text { (FN706550) }\end{array}$ \\
\hline $\begin{array}{l}\text { Acremonium } \\
\text { sclerotigenum }\end{array}$ & B2078 & cold water & Molecular & - & MZ190340 & & - \\
\hline $\begin{array}{l}\text { Acremonium } \\
\text { sclerotigenum }\end{array}$ & B2080 & cold water & Molecular & MT320766 & - & 0.97 & [22] (NR_149332) \\
\hline $\begin{array}{l}\text { Acremonium } \\
\text { sclerotigenum }\end{array}$ & B2131B & cold water & Molecular & MT320775 & MZ190338 & 0.2 & [22] (NR_149332) \\
\hline $\begin{array}{l}\text { Acremonium } \\
\text { sclerotigenum }\end{array}$ & B2081 & hot water & Molecular & MT320773 & - & 0.98 & [22] (NR_149332) \\
\hline $\begin{array}{l}\text { Acremonium } \\
\text { sclerotigenum }\end{array}$ & В03ТВ & tray swab & Molecular & - & MZ190332 & - & - \\
\hline Acremonium sp. & B20A & cold water & Morphological & - & - & 0.33 & - \\
\hline Acremonium sp. & B2242B & cold water & Morphological & - & - & 0.27 & - \\
\hline Acremonium sp. & B4003B & cold water & Morphological & - & - & 0.02 & - \\
\hline Acremonium sp. & B4005A & cold water & Morphological & - & - & 1 & - \\
\hline Acremonium sp. & B4402A & cold water & Morphological & - & - & 0.94 & - \\
\hline Acremonium sp. & B11CB & tap swab & Morphological & - & - & - & - \\
\hline Acremonium sp. & B22TD & tray swab & Morphological & - & - & - & - \\
\hline Acremonium sp. & B33TA & tray swab & Morphological & - & - & - & - \\
\hline Aspergillus jensenii & B19CSA & tap swab & Molecular & MT320779 & - & - & [23] (NR_135444) \\
\hline Aspergillus steynii & B2132B & cold water & Molecular & - & MZ190334 & 0.02 & - \\
\hline Aspergillus sp. & B2132C & cold water & Morphological & - & - & 0.53 & - \\
\hline Aspergillus sp. & B2245D & cold water & Morphological & - & & 0.04 & - \\
\hline Aureobasidium sp. & B2245G & cold water & Morphological & - & - & & - \\
\hline Aureobasidium sp. & B14TD & tray swab & Molecular & - & MZ190333 & - & - \\
\hline Blastobotrys sp. & B4008C & cold water & Morphological & - & - & 0.08 & - \\
\hline Cadophora malorum & B2130D & cold water & Molecular & MT320771 & - & 0.07 & [24] (NR_145268) \\
\hline Candida oleophila & B37TC & tray swab & Molecular & MT320774 & - & - & [25] (NR_155224) \\
\hline Chaetothyriales sp. & B2244E & cold water & Molecular & - & MZ190326 & 0.13 & - \\
\hline $\begin{array}{l}\text { Cladosporium } \\
\text { cladosporioides }\end{array}$ & B16HA & cold water & Morphological & - & - & 0.29 & - \\
\hline $\begin{array}{l}\text { Cladosporium } \\
\text { cladosporioides }\end{array}$ & B19TA & tray swab & Morphological & - & & - & - \\
\hline $\begin{array}{l}\text { Cladosporium } \\
\text { halotolerans }\end{array}$ & B2130A & cold water & Molecular & MT320762 & - & 0.79 & $\begin{array}{c}{[26]} \\
\left(\mathrm{NR} \_119605 / \mathrm{DQ780364}\right)\end{array}$ \\
\hline Cladosporium sp. & B2132F & cold water & Morphological & - & - & 0.07 & - \\
\hline Cladosporium sp. & В05ТВ & tray swab & Morphological & - & - & - & - \\
\hline Cladosporium sp. & В09ТВ & tray swab & Morphological & - & - & - & - \\
\hline Cladosporium sp. & B09TC & tray swab & Morphological & - & - & - & - \\
\hline Cladosporium sp. & В19ТВ & tray swab & Morphological & - & - & - & - \\
\hline Cladosporium sp. & B23TC & tray swab & Morphological & - & - & - & - \\
\hline Cladosporium sp. & B30T & tray swab & Morphological & - & - & - & - \\
\hline Cryptococcus sp. & B4009A & cold water & Morphological & - & - & 0.93 & - \\
\hline Cylindrocarpon $\mathrm{sp}$. & B4390B & cold water & Morphological & - & - & 0.47 & - \\
\hline Cystobasidium minutum & В15TB & tray swab & Molecular & - & MZ190335 & - & - \\
\hline Cystobasidium slooffiae & B2242A & cold water & Molecular & MT320776 & - & 0.04 & $\begin{array}{c}{[27]} \\
\text { (NR_103568/AF444627) }\end{array}$ \\
\hline Cystobasidium slooffiae & B14TC & tray swab & Molecular & MT320767 & - & - & $\begin{array}{c}{[27]} \\
\text { (NR_103568/AF444627) }\end{array}$ \\
\hline Cystobasidium slooffiae & B2130B & cold water & Molecular & MW166334 & - & 0.13 & $\begin{array}{c}{[27]} \\
\text { (NR_103568/AF444627) }\end{array}$ \\
\hline Didymella protuberans & B2245A & cold water & Molecular & MT320764 & - & 0.02 & $\begin{array}{c}{[28]} \\
\text { (NR_135993/GU237853) }\end{array}$ \\
\hline Exophiala alcalophila & B0708C & tap swab & Molecular & МТ320777 & - & - & [29] (NR_111624) \\
\hline Exophiala equina & B4003A & cold water & Molecular & MT320769 & - & 0.7 & [29] (NR_111627) \\
\hline Exophiala lecanii-corni & B2242C & cold water & Molecular & MT320770 & MZ190330 & 0.63 & $\begin{array}{c}{[30]} \\
\text { (NR_145351/AY857528) }\end{array}$ \\
\hline Exophiala lecanii-corni & B4003D & cold water & Molecular & MT320768 & - & 0.14 & $\begin{array}{c}{[30]} \\
\text { (NR_145351/AY857528) }\end{array}$ \\
\hline Exophiala sp. & B11CA & tap swab & Molecular & - & MZ190337 & - & - \\
\hline Fusariumdimerum & B02TC & tray swab & Molecular & MT320778 & - & - & [31] (NR_137706) \\
\hline Fusarium sp. & B2132G & cold water & Morphological & - & - & 0.16 & - \\
\hline Geotrichum sp. & B2244B & cold water & Morphological & - & - & 0.07 & - \\
\hline
\end{tabular}


Table 2. Cont.

\begin{tabular}{|c|c|c|c|c|c|c|c|}
\hline \multirow[t]{2}{*}{ Identification } & \multirow[t]{2}{*}{ ID } & \multirow[t]{2}{*}{ Type } & \multirow{2}{*}{$\begin{array}{c}\text { Identification } \\
\text { Type }\end{array}$} & \multicolumn{2}{|c|}{$\begin{array}{c}\text { GenBank Accession } \\
\text { Number of: }\end{array}$} & \multirow{2}{*}{$\begin{array}{l}\text { Relative } \\
\text { Frequency in } \\
\text { the Sample }\end{array}$} & \multirow[t]{2}{*}{ Reference } \\
\hline & & & & ITS & tef1 $\alpha$ & & \\
\hline Gliomastix polychroma & B2245B & cold water & Molecular & МT320759 & - & 0.02 & [32] (NR_119408) \\
\hline Gliomastix sp. & В33ТВ & tray swab & Morphological & - & - & - & - \\
\hline $\begin{array}{l}\text { Meyerozyma } \\
\text { guilliermondii }\end{array}$ & B02TA & tray swab & Molecular & MT320761 & - & - & [25] (KY104252) \\
\hline Oidiodendron sp. & B31TA & tray swab & Morphological & - & - & - & - \\
\hline Paecilomyces sp. & B19CSA & tap swab & Morphological & - & - & - & - \\
\hline Penicilliumchrysogenum & B2132A & cold water & Molecular & MT320763 & MZ190336 & 0.05 & [33] (NR_111815) \\
\hline Penicillium sp. & B4008A & cold water & Morphological & - & - & 0.82 & - \\
\hline Penicillium sp. & B15CSA & tap swab & Morphological & - & - & - & - \\
\hline Penicillium sp. & B20TA & tray swab & Morphological & - & - & - & - \\
\hline Penicillium sp. & B23TA & tray swab & Morphological & - & - & - & - \\
\hline Penicillium sp. & В23ТВ & tray swab & Morphological & - & - & - & - \\
\hline Phaeoramularia sp. & B4397MA & hot water & Morphological & - & - & 0.5 & - \\
\hline $\begin{array}{c}\text { Purpureocillium } \\
\text { lilacinum }\end{array}$ & B32TA & tray swab & Molecular & - & MZ190328 & - & - \\
\hline $\begin{array}{l}\text { Purpureocillium } \\
\text { lilacinum }\end{array}$ & B2130C & cold water & Molecular & - & MZ190339 & & - \\
\hline Pyricularia sp. & B34CSA & tap swab & Morphological & - & - & - & - \\
\hline Rhodotorula sp. & B2245E & cold water & Morphological & - & - & 0.14 & - \\
\hline Rhodotorula sp. & B2245F & cold water & Morphological & - & - & 0.07 & - \\
\hline Rhodotorula sp. & В02ТВ & tray swab & Morphological & - & - & - & - \\
\hline Rhodotorula sp. & B0708T & tray swab & Morphological & - & - & - & - \\
\hline Rhodotorula sp. & B09TA & tray swab & Morphological & - & - & - & - \\
\hline Rhodotorula sp. & B14TB & tray swab & Morphological & - & - & - & - \\
\hline Rhodotorula sp. & B15TC & tray swab & Morphological & - & - & - & - \\
\hline Rhodotorula sp. & B28TA & tray swab & Morphological & - & - & - & - \\
\hline Sarocladium kiliense & B2244D & cold water & Molecular & - & MZ190325 & 0.36 & - \\
\hline Scopulariopsis sp. & B22TE & tray swab & Morphological & - & - & - & - \\
\hline $\begin{array}{l}\text { Simplicillium } \\
\text { cylindrosporum }\end{array}$ & B2132E & cold water & Molecular & MT320760 & - & 0.33 & [34] (NR_111023) \\
\hline Simplicilliumlanosoniveum & B4009B & cold water & Molecular & MT320765 & MZ190331 & 0.05 & [34] (NR_111025) \\
\hline Simplicillium minatense & B2132D & cold water & Molecular & - & MZ190329 & 0.27 & - \\
\hline Simplicillium minatense & B22TA & tray swab & Molecular & - & MZ190327 & - & - \\
\hline Simplicillium sp. & B4008B & cold water & Morphological & - & - & 0.003 & - \\
\hline Talaromyces sp. & B23TD & tray swab & Morphological & - & - & - & - \\
\hline Trichosporon sp. & B37TA & tray swab & Morphological & - & - & - & - \\
\hline $\begin{array}{l}\text { Unidentified } \\
\text { filamentous sp. }\end{array}$ & B09TD & tray swab & Morphological & - & - & - & - \\
\hline $\begin{array}{l}\text { Unidentified } \\
\text { filamentous sp. }\end{array}$ & B2131A & cold water & Morphological & - & - & 0.1 & - \\
\hline $\begin{array}{l}\text { Unidentified } \\
\text { filamentous sp. }\end{array}$ & B2244A & cold water & Morphological & - & - & 0.07 & - \\
\hline $\begin{array}{l}\text { Unidentified } \\
\text { filamentous sp. }\end{array}$ & B4007A & cold water & Morphological & - & - & 0.08 & - \\
\hline $\begin{array}{l}\text { Unidentified } \\
\text { filamentous sp. }\end{array}$ & B4390A & cold water & Morphological & - & - & 0.50 & - \\
\hline $\begin{array}{l}\text { Unidentified } \\
\text { filamentous sp. }\end{array}$ & B14MA & hot water & Morphological & - & - & 0.8 & - \\
\hline Unidentified yeast sp. & B03TA & tray swab & Morphological & - & - & - & - \\
\hline Unidentified yeast sp. & B05TA & tray swab & Morphological & - & - & - & - \\
\hline
\end{tabular}

\subsection{Physical, Chemical and Biological Descriptional Statistics}

According to the questionnaire-based survey, no complaints have been reported about the organoleptic characteristics of the water provided by the BWDs. Organoleptic testing during sampling confirmed this finding. In total $58 \%$ of the sampled water bottles contained mineral water which was not treated or disinfected.

Table S5 contains the descriptive statistics of the measured numerical variables. In most cases the concentration of the nitrogen forms was under the limit of detection, nitrite ion was detected in $8.1 \%$ and ammonium ion in $13.5 \%$ of the water samples. Pseudo hardness (carbonate hardness belonging to monovalent cations) was present in $24.3 \%$ of the water samples. 
The HPC results were high, in several cases $\left(19 / 37\right.$ at $22^{\circ} \mathrm{C}$ and $14 / 37$ at $\left.37{ }^{\circ} \mathrm{C}\right)$ exceeding the upper limit of quantification $(10,000 \mathrm{CFU} / \mathrm{mL})$. Pseudomonas aeruginosa was detected in $10.8 \%$ of the dispensers.

The HPC values incubated at 22 and $37^{\circ} \mathrm{C}$ correlated $\left(p=8 \times 10^{-11} ; \mathrm{R}=0.84\right)$. Both of them had positive relationships with the TOC results $\left(p=0.0023 ; \mathrm{R}=0.5\right.$ at $22{ }^{\circ} \mathrm{C}$ and $p=0.0014 ; \mathrm{R}=0.52$ at $37^{\circ} \mathrm{C}$, Figure S4) and a negative correlation with the number of days remaining until the expiration date of the bottles $\left(p=0.0295 ; \mathrm{R}=-0.37\right.$ at $22{ }^{\circ} \mathrm{C}$ and $p=0.0458 ; \mathrm{R}=-0.34$ at $37^{\circ} \mathrm{C}$, Figure S1) according to Pearson correlation. The $\mathrm{HPC}$ at $37^{\circ} \mathrm{C}$ also correlated with the number of days since the last maintenance and/or disinfection $(p=0.0478 ; \mathrm{R}=-0.43)$. The log transformed total HPC results correlated negatively with the filamentous fungal counts of the water samples $(p=0.036, \mathrm{R}=-0.38)$ (Figure S5).

The month of sampling ( $p=0.0051$ at $22{ }^{\circ} \mathrm{C}$ and $p=0.0004$ at $37^{\circ} \mathrm{C}$, Figure S2), the type of the institution $\left(p=0.002\right.$ at $22^{\circ} \mathrm{C}$ and $p=0.0012$ at $37^{\circ} \mathrm{C}$, Figure S6) and the frequency of the disinfection process ( $p=0.0159$ at $22^{\circ} \mathrm{C}$ and $p=0.0067$ at $37^{\circ} \mathrm{C}$ ) affected the HPC values most significantly. Only $16.2 \%$ of the examined BWDs were disinfected more often than monthly, $18.9 \%$ every $1-2$ month, $27 \%$ every $3-4$ month, $2.7 \%$ every $5-6$ month, $8.1 \%$ yearly and $24.3 \%$ less often than yearly. One of the examined BWDs was never disinfected.

BWDs used by the personnel had worse $(p=0.0252)$ and by customers had better $(p=0.0123) \mathrm{HPC}$ results at $22{ }^{\circ} \mathrm{C}$. Presumably it is connected to types of institutions, as BWDs used by customers with the lowest HPC counts operated mostly in pharmacies, while personnel used BWDs with the highest HPC counts mainly operated in private hospitals and dental clinics. BWDs containing air filter also were contaminated $(p=0.0136)$. If disinfection is performed by the staff besides the routine maintenance, both HPC values were better $\left(p=0.0011\right.$ at $22^{\circ} \mathrm{C}, p=0.0031$ at $\left.37^{\circ} \mathrm{C}\right)$. BWDs installed in waiting areas had higher HPC values at $37^{\circ} \mathrm{C}(p=0.0491)$. Devices not exposed to any sunlight had better results at both temperatures ( $p=0.0221$ at $22{ }^{\circ} \mathrm{C}$ and $p=0.0336$ at $37^{\circ} \mathrm{C}$ ). Furthermore, if the bottles had not been exposed to any sunlight during storage, it had a favorable effect on the $\mathrm{HPC}$ at $37^{\circ} \mathrm{C}(p=0.0407)$.

$P$. aeruginosa numbers [CFU $/ 100 \mathrm{~mL}$ ] correlated with the detected nitrite ion concentrations $[\mathrm{mg} / \mathrm{L}](p=0.0016 ; \mathrm{R}=0.5)$ and with the number of yeasts in swab samples collected from the tap of BWDs $(p=0.0348 ; \mathrm{R}=0.35)$.

\subsection{Questionnaire}

Most of the sampled BWDs were located in hospitals: $37.8 \%$ in private and $18.9 \%$ in state hospitals, but some operated in dental clinics (27\%) and pharmacies (16.2\%). Samples were collected in April (35.1\%), June (27\%) and July (37.8\%) of 2018. Most BWDs were positioned in the waiting rooms, on the corridors or in the kitchen $(62.2 \%, 27 \%$ and $18.9 \%$, respectively). Usually, devices are used by both the staff and patients $(83.8 \%$ and $81.1 \%$, respectively, or customers $16.2 \%$ ). Some BWDs were able to provide carbonated water $(24.3 \%)$, though we did not use this function during sampling. The examined BWDs were manufactured by eight different manufacturers (although $37.8 \%$ was the same brand), and $48.6 \%$ contained air filter according to their user's manual. Usually, the disinfection process is part of the maintenance provided by the manufacturer or distributor, but in $18.9 \%$ the operating personnel also performs disinfection. Most of the BWDs were not exposed to sun (46.8\%), 35.5\% were affected by diffuse and $16.2 \%$ by direct sunlight, although only through a window. Bottles during storage were not exposed to sunlight in $64.9 \%$, only to diffuse sunlight in $29.7 \%$ and to direct sunlight in $5.5 \%$ of the cases, also through the window glass The quantity of bottles ordered at once was one to five $(37.8 \%)$, six to ten $(24.3 \%)$, eleven to twenty $(21.6 \%)$ or even more bottles $(16.2 \%)$, although some facilities where the sampling was performed operate more BWDs beside the one we collected information on. More than $94 \%$ of the sampled BWDs provided mineral water. Numerical variables are described in Table S6. 


\section{Discussion}

BWDs are mainly made of plastic (PVC, PE, PB, PP), but also contain metal parts and rubber seals. Most of these are in contact with water, therefore bacteria and fungi are able to form biofilms on their surface and colonize these materials. The presence of various materials in a water system is known to enhance microbial growth and biofilm formation [35]. In this study, the authors did not investigate the effects on microbes caused by the different materials found in a BWD, as the biofilm forming properties had already been investigated by Pinto et al. [35]. We hypothesize that the accessibility of BWD parts (e.g., parts that are visible vs. parts that always remain hidden) could play a more important role in biofilm formation, than the BWD's material itself.

The main objective of the study of Yamaguchi et al. [12] was the most similar to ours. However, their observations occurred in residential and office buildings in Brazil, while our study was carried out in healthcare institutions in a European country. There are higher risks of fungal infections via BWDs in hospitals and pharmacies where immunocompromised people may frequently use these devices or, multi-resistant yeasts can colonize surfaces of water-connected equipment. In the case of Yamaguchi et al. [12] it is not clear whether sampling water of BWDs occurred by opening the tap (water goes through the pipes of the device) or directly from the bottles. They found that the bottled mineral water was more contaminated than municipal tap water. The recovery of yeasts was significantly higher in bottled water than in tap water. Their observations were based on $20 \mathrm{~L}$ bottled mineral and tap water samples $(n=60)$, including fungal and bacterial (HPC, total coliform) investigations. The sampled water bottles in their study contained mineral water produced by a specific company. Such water cannot be treated nor added any exogenous elements. In our study we sampled 9 companies' products. Five of them produced mineral water which was not disinfected. The others provided treated tap water or spring water. In our case, in total $58 \%$ of the sampled water bottles contained mineral water. They found Candida spp. as the most prevalent yeasts in the bottled water, including C. parapsilosis and C. glabrata as well. The authors highlighted that these species may cause nosocomial infections and raise the risk of candidaemia. In the last decade, multi-resistant $C$. auris (called also as 'super yeast') is an emerging problem in hospitals worldwide (including Europe) [36,37]. Such pathogen was detected in biofilms of catheters [38,39]. One can speculate that this fungus may colonize water pipes of BWDs as well. However, Candida species were relatively rare in our samples. The difference between Brazilian and Hungarian results remained unclear. Climate, as a factor may explain the difference between the results of these countries. Contrariwise to BWDs, pathogenic Candida spp. were found to be common in domestic washing machines in Hungary [9,40]. Candida species occurred frequently in such water-connected devices, mostly in hardly accessible parts of them. Further research is needed to survey the occurrence of the pathogenic Candida spp. in other water-connected devices of hospitals beyond BWDs.

\subsection{Statistical Relationship of Fungi and Bacteria in BWDs}

Fungi and bacteria often share common substrates, and their spatial proximity has led to antagonistic interactions in many environments, including aquatic ones [41]. This may explain our results of negative correlation between filamentous fungi and total HPC in water samples. If more time passed since the production date of the bottles, bacteria were more likely to proliferate in contrast to filamentous fungi. Furthermore, seasonal fluctuation was also observed, in April higher filamentous fungal counts have been experienced compared to July, when HPC results were significantly greater. Furthermore, in warmer months water consumption increases, therefore the connection between the higher quantity of ordered bottles and the lower number of yeasts in water might be also a seasonal consequence. Exposition of BWDs to sun-increasing water temperature-enhanced both HPC results, while exposition of water containers during storage increased only HPC at $37^{\circ} \mathrm{C}$. At the same time, filamentous fungal counts decreased significantly only during storage as a result of exposition to sunlight. It suggests that filamentous fungi and some 
bacteria proliferating at $37^{\circ} \mathrm{C}$ are already present in the bottles. Previous studies on bottled water also reported about the presence of fungal contamination [3]. Furthermore, there is evidence of the bacterial contamination of the bottles of BWDs in Hungary as well. Thirteen bottles had been sampled, where two bottles contained P. aeruginosa, seven had high $\left(>1000 \mathrm{CFU} / \mathrm{mL}\right.$ ) bacterial concentration at $22{ }^{\circ} \mathrm{C}$, though only one had elevated counts $(3800 \mathrm{CFU} / \mathrm{mL})$ at $37{ }^{\circ} \mathrm{C}$ (unpublished data of Ágnes Sebestyén). On the other hand, several further parameters are connected mainly to operational and usage habits affect bacteria forming colonies at $22{ }^{\circ} \mathrm{C}$ - such as the type of institution, air filter in BWDs and the circle of users -, indicating that the contamination might originate partly from the devices' inner environment. Furthermore, the HPC values at $37^{\circ} \mathrm{C}$ were higher in case of BWDs operating in waiting areas of healthcare facilities, where presumably the device is accessed by more people with various hygienic habits. Filamentous fungal counts have decreased after maintenance or disinfection, while HPC values at $37^{\circ} \mathrm{C}$ have increased.

Yamaguchi et al. [12] found positive correlation between HPC values and yeasts and HPC values and filamentous fungi, which is in contrast with our findings. Month of sampling (seasonal changing) and climate seem to have a major effect on the microbial contamination of stored bottles. Further conclusions cannot be drawn as we have no information about temperature and sampling season affecting microbial contamination of BWDs in Brazil.

Table S7 summarizes the related legislations of the European Union and Hungary for the tested microbial water quality parameters.

If the plate count in the bottle is assumed to be constant from bottling (which is generally not the case), values should not be higher than 10,000 CFU / mL and $2000 \mathrm{CFU} / \mathrm{mL}$ counts for HPC at 22 and $37^{\circ} \mathrm{C}$, respectively, based on the recommendation of Water Coolers Europe for BWDs. Compared to these values, $21.62 \%$ of water samples was compliant, $2.7 \%$ and $27.03 \%$ were non-compliant due to $\mathrm{HPC}$ at $22{ }^{\circ} \mathrm{C}$ and $37{ }^{\circ} \mathrm{C}$, respectively, and in $48.65 \%$ both HPC results were non-compliant. None of the samples met the Hungarian empirical reference values used for drinking water.

\subsection{Fungi in Water Samples, on Drip Trays and on Taps}

According to our knowledge, this is the first study aiming to evaluate the fungal contamination and its causal factors in case of BWDs in Europe. Majority (86.8\%) of the water samples were contaminated with fungi. In an unpublished survey of 33 BWDs in 2014 , we found fungi in less $(60.6 \%)$ water samples. The composition of fungi was also somewhat different (the most frequent fungi were Cladosporium (being present in $24 \%$ of the water samples and comprising $8 \%$ of the isolated fungal taxa) and Penicillium (18\% of the water samples, $6 \%$ of the isolated fungal taxa), while Botryotinia californica, Exophiala equina and Rhodotorula spp. were also present). The difference in fungal contamination found in our previous and current study may be explained by the location of BWDs, as BWDs of the former sampling campaign were selected not only from healthcare institutions, but also from office buildings. Climatization and air filtration units are common in office buildings and provide low fungal concentration of the indoor air, because such devices filter out fungal spores from the air. In contrast, such mechanical ventilation systems are rare in healthcare facilities of Hungary [42,43]. Therefore, airborne contamination of BWDs seems to be more probable in healthcare facilities than in office buildings of Hungary. In the current study, $75.0 \%$ of fungal taxa isolated from water samples belonged to filamentous fungi, and $63.0 \%$ of them is characterized by slimy colonies and hydrophilic spores (gloiospores). This latter morphological character facilitates waterborne dispersal of spores [44]. Yeasts produce hydrophilic spores too. Therefore, most of the fungal taxa $(72.2 \%)$ found in water samples of BWDs seem to be present due to a micro-environmental selection, favoring the waterborne dispersal. In contrast, hydrophilic taxa are less abundant in tray swab samples (52.6\%). Cladosporium and Rhodotorula spp. dominate tray samples, which are also common in the air samples collected in Hungary (Donát Magyar, unpublished data). Their spores, settling from the air, often colonize surfaces covered with a thin film of water 
(e.g., condensate on window frames and drip trays, as in this case). Even though the contamination of BWDs from the air is probable, still remains speculative, therefore future studies should be designed to collect airborne fungi during water sampling.

Usually, $\mathrm{pH}$ is an important environmental parameter affecting fungal growth [45]. Counts of fungi in BWDs showed positive correlation with $\mathrm{pH}$ (range: 7.1-10.8). This finding is in contradiction to our previous results, where fungal counts of washing machines showed negative correlation with $\mathrm{pH}$ (range: 7-10.9) [9]. Low $\mathrm{pH}$ in washing machines is possibly due to the use of detergents, but such chemicals are not applied in BWDs. Even though water is a key environmental determinant in both devices, BWDs and washing machines offer a quite different environment for fungi.

Concentration of yeasts in water-similar to P. aeruginosa, capable to produce nitrite reductase enzyme [46] — correlated positively with nitrite ion concentration. Several species of the isolated yeasts or yeast-like genera are able to grow on nitrite (Cryptococcus spp., Exophiala spp., Meyerozyma spp., Rhodotorula spp., Trichosporon spp.) [47-49] or to reduce nitrate to nitrite or through nitrite to $\mathrm{N}_{2} \mathrm{O}$ or ammonia (Acremonium spp., Aureobasidium spp., Blastobotrys spp., Cryptococcus spp., Exophiala spp., Geotrichum spp., Meyerozyma spp., Rhodotorula spp.) [50-56]. Some genera might be able to oxidize nirite to nitrate (Meyerozyma guilliermondii, Geotrichum spp., Rhodotorula spp.) [57]. The possibility of a complex relationship between yeasts in water, P. aerugimosa and the nitrite ion concentration should be further investigated.

Counts of filamentous fungi and yeasts correlated, while Yamaguchi et al. [12] found no significant correlation between their occurrence in the bottled water samples [12]. These results also show the differences between the studies carried out in different climatic regions.

Air filters of BWDs are usually part of the water guard, directly contacting the bottles. These filters are able to keep out particles over $25 \mu \mathrm{m}$, while the size of fungal conidia common in the air may vary between $2-20 \mu \mathrm{m}$ and bacterial cells fall between $0.5-1 \mu \mathrm{m}$, therefore contamination from the environment of BWDs is possible. The linkage between the presence of air filter and higher count results of HPC at $22{ }^{\circ} \mathrm{C}$ from water samples may be a result of airborne bacteria entering the device through the filter. In respect of the linkage between the presence of air filter and higher fungal contamination of drip trays the above-mentioned contamination pathway is less likely, as the air filter and drip tray are spatially separated. It is more likely that the drip tray is contaminated from the air. Not just the parameters of BWDs and usage habits, but also the exposition to sun during storage affected the filamentous fungal counts of drip trays. Therefore, we should assume that the contamination partly originates from the water itself and also from the air; and develops as biofilms with different species composition on surfaces exposed to air and water (drip trays and inner surfaces of the BWD, respectively).

Results of total fungi on the taps are mainly derived from the high concentration of yeasts. Their number decreased with higher alkalinity, total and temporary hardness. Several studies have shown that calcium increases surface attachment and biofilm production by many bacteria and fungi [58-62]. Divalent cations may play a role in the maintenance of biofilm structure as bridging agents, crosslinking the three-dimensional extracellular polymeric matrix $[63,64]$, therefore hardening the formed biofilm [65]. Swab sampling has the disadvantage of providing information only about the immediate surface of a biofilm, unless the biofilm is soft enough to detach from its support during swabbing. In the latter case, yeast cells of deeper biofilm layers are also collected, which produces higher CFU values, therefore might explain the negative correlation of hardness with yeast numbers. Products of one manufacturer had significantly worse results, than two of the eight other manufacturers, indicating that yeast contamination of taps are dependent on the structure or material of the BWDs as well.

Counts of filamentous fungi on taps correlated with those counts of water samples, as well as with the expiration date of bottles. Therefore, filamentous fungi found on the taps 
might mainly originate from the bottles and inner pipelines which would contaminate the drained water (although some usage habits also affected the quality, but less significantly).

\subsection{Health Considerations}

Several opportunistic human pathogenic fungi were detected in the samples collected from BWDs, especially from water and tap surfaces, e.g., Sarocladium kiliense (previously isolated from clinical samples of vitreous fluid, cornea, sinus, bronchoalveolar lavage, esophagus, sputum, skin and toenail, etc. [66]), Acremonium sclerotigenum/egyptiacum (has been cultured from clinical samples of tracheal aspirate sinus, cerebrospinal fluid, bronchoalveolar lavage, sputum and toenail, etc. [22]), Exophiala jeanselmei var. lecanii-corni (has been linked to several systematic and localized cutaneous infections, known as causative agent of keratitis, pneumonia and other infections [67,68]), Exophiala equina (has been linked only to subcutaneous phaeohyphomycosis so far [69]), Meyerozyma guilliermondii (considered to have low pathogenicity, but has been found in respiratory, genital, soft tissue and skin specimens [70,71]), Cystobasidium slooffiae (has been linked to fungemia, endocarditis and meningitis [72]), Aspergillus jensenii (has been isolated from bronchoalveolar lavage, sputum and nail [73]), Fusarium (Bisifusarium) biseptatum (has been reported to cause trauma-related eye infection [31]), Penicillium rubens (has an ability to grow at $37^{\circ} \mathrm{C}$ and was detected in several clinical samples from humans [74]), Cladosporium halotolerans (is not associated with human infection, but has been isolated from a number of clinical samples [75]). Rhodotorula species often colonize moist tubes, such as catheters ( $R$. mucilaginosa is able to cause catheter-related fungemia) or hoses of aquarium filters. In our case, it is possible that these fungi colonized the plastic pipes in BWDs. Even though fungi are not considered as enteric pathogens, therefore their presence in drinking water is usually harmless, but patients after certain dental treatments might be at risk. Furthermore, these devices might act as sources of contamination accumulating opportunistic pathogenic species.

\section{Materials and Methods}

\subsection{Study Design}

A questionnaire was designed to provide information on the usage and disinfection habits of BWDs in Budapest, Hungary. For physical, chemical and biological observations 37 BWDs were sampled during the spring and summer of 2018. The sampled BWDs are located in medical institutions (7 in public hospitals, 14 in private hospitals, 7 in pharmacies and 10 in dentistries). The questionnaires were anonymously filled by the participants of the survey.

\subsection{Questionnaire}

The standardized questionnaire contained 17 questions, filled for each device by the operator/people in charge or other workers of the facilities on the usage and maintenance practice of the dispenser and the storage rooms of the device and the bottles. Furthermore, a record sheet has been filled, containing questions answerable by the samplers and onsite measurement results (temperature and relative humidity of the BWD's and bottles' storage rooms measured by Testo $174 \mathrm{H}$ portable temperature and humidity meter) (See Supplement 1. Questionnaire).

\subsection{Sampling}

Samples were collected from the cold water by opening the dispenser tap of the BWD according to EN ISO 19458. For microbiological and chemical analysis, $1 \mathrm{~L}$ cooled water samples were collected without purge in sterile glass bottles, while measuring the time needed to reach the volume. Furthermore, $250 \mathrm{~mL}$ cold water samples were also collected into acidified glass bottles for TOC analysis (rinsing the container 3 times before). For further microbiological analyses $500 \mathrm{~mL}$ heated water samples were collected into sterile glass bottles. Some additional cold water was taken to a small clean plastic glass to measure the temperature and $\mathrm{pH}$ on site and this process was repeated with hot water, where the 
device was able to provide it as well. Approximately one square $\mathrm{cm}$ of swab samples (by a sterile cotton tipped applicator with plastic shaft from Biolab Inc., St, Ontario, CA, USA) were collected from drip trays and taps, respectively, and spread onto malt extract agar (MEA) with $2 \%$ chloramphenicol on site. All samples have been transported in a cooler box $\left(4-10^{\circ} \mathrm{C}\right)$ to the National Public Health Center within 1-3 h, where they were uniformly stored at $4{ }^{\circ} \mathrm{C}$ until processing. The collected water samples were divided for the different analyses in lab conditions. TOC samples were acidified to $\mathrm{pH}<2$.

\subsection{Physical Analyses}

The following physical parameters were tested: temperature $\left({ }^{\circ} \mathrm{C}\right.$, on site by using Testo 206-pH1, Testo INC, Lenzkirch, Germany), taste and odor (based on the experience of the operator of the BWD), conductivity (WTW inoLab Cond Level 2 was used with a WTW TetraCon 325 cell, Xylem INC, Global), volume flow (on site, time necessary to draw $1 \mathrm{~L}$ of cold water sample from the BWD, expressed in seconds/L).

\subsection{Chemical Analyses}

The following parameters have been measured: $\mathrm{pH}$ (on site by a Testo 206-pH1, Testo INC, Lenzkirch, Germany), alkalinity (MSZ 448-11:1986), total hardness (MSZ 44821:1986), ammonium (MSZ ISO 7150-1:1992), nitrite concentration (MSZ 1484-13:2009), total organic carbon (TOC/TNb elementar vario TOC cube, Elementar Analysensysteme $\mathrm{GmbH}$, Langenselbold, Germany).

\subsection{Microbiology}

Heterotrophic plate counts (HPC) at $22{ }^{\circ} \mathrm{C}$ and $37^{\circ} \mathrm{C}$ were determined according to the MSZ EN ISO 8199:2005 [76] and detection and quantification of P. aeruginosa were performed according to the MSZ EN ISO 16266:2006 [77] standards.

For the characterization of fungal contamination of the drinking water, $100 \mathrm{~mL}$ water sample was concentrated on cellulose nitrate membrane filter (pore diameter: $0.45 \mu \mathrm{m}$ ) by using a two-stage vacuum pump. Filters were placed on malt extract agar (MEA) with $2 \%$ chloramphenicol. Plates were incubated at $25^{\circ} \mathrm{C}$ for 5 days. The incubation temperature is based on the usual temperature of the environment by the devices, while the number of days were decreased to 5 days (the Swedish legislation use 7 days-Babic et al. 2017), as several samples were highly contaminated. Following the incubation, fungal colonies have been counted and common $(>4 \mathrm{CFU} / 100 \mathrm{~mL})$ morphotypes were selected for isolation to potato dextrose agars (Biolab Inc.) containing 0.02\% streptomycin (Sigma-Aldrich Chemie Gmbh., St. Louis, MO, USA). Isolated and purified strains were identified at the genus level based on their morphological characteristics examined by a Carl Zeiss Jenaval light microscope at $300 \times$ magnification. The most common species have been identified at species level based on molecular characterization of the internal transcribed spacer region of the ribosomal RNA gene cluster enclosed by the ITS1F Forward (5'-CTT GGT CAT TTA GAG GAA GTA A-3') and ITS4 Reverse primers (5'-TCC TCC GCT TAT TGA TAT GC- $\left.3^{\prime}\right)[78,79]$. For subsets of the isolates a fragment of the translation elongation factor (tef) $1 \alpha$ gene was also amplified with primers EF1-728F (5'-CATCGAGAAGTTCGAGAAGG) and TEF-LLErev (5'-AACTTGCAGGCAATGTGG) following the protocol described by Hatvani et al. [80]. Sanger-sequencing of the amplicons was performed on ABI 3130 Genetic Analyzer (Applied Biosystems, USA) at Institute of Aquaculture and Environmental Safety, Gödöllő and 3500 Genetic Analyzer (Life Technologies) at BayGen, Szeged. Species identification was performed by nucleotide-nucleotide BLAST analysis [81] at the website of the National Center of Biotechnology Information (NCBI, www.ncbi.nlm.nih.gov, accessed on 9 July 2021).

\subsection{Statistical Analysis}

In many samples, the HPC values exceeded the upper limit of quantification $(10,000 \mathrm{CFU} / \mathrm{mL})$, thus for the statistical analyses an ordinal scale was generated by cate- 
gorizing the data into groups of $500 \mathrm{CFU} / \mathrm{mL}$ increments, where the last group contains the samples exceeding $9500 \mathrm{CFU} / \mathrm{mL}$.

For the determination of connections between parameters, we used Pearson correlation with Benjamini-Hochberg correction for the numerical variables (where appropriate, we applied data transformation technics), and Pairwise Wilcoxon-Mann-Whitney test also with Benjamini-Hochberg correction for factors, which are less sensitive for unbalanced data.

All statistical calculations have been performed in R-statistics (www.r-project.org, accessed on 9 July 2021).

\section{Conclusions}

The modern lifestyle and the change of water consumption habits, including the use of new water-containing household devices such as bottled water dispensers require constant improvement of regulations, water purification and monitoring practices. The present study revealed that bottled water dispensers provide excellent habitat for manifold microorganisms. According to our two previous works $[3,82]$ and the present one, it can be concluded that a high percentage of BWDs are contaminated with bacteria, filamentous fungi and yeasts. Such microorganisms are able to proliferate in the bottled water, disperse inside the BWD devices and colonize their surfaces, which may pose a health risk especially for immunocompromised people visiting healthcare institutions. Stagnant water in the bottle and the device is disadvantageous. It is advisable to optimize the storage time, as well as the time while the bottle is in use. Most optimal if the bottle is replaced after 2-3 days, regardless of how much water is consumed. Regular and professional cleaning of the devices is recommended. Considering the number and variety of identified pathogens, operation of BWDs in high-risk areas such as health care facilities should be a concern, and other means of providing staff and patients with safe drinking water should be preferred. Our study (conducted in a country of well-regulated water hygiene system) draws attention to the need of considering the risks associated with fungi in BWDs in other parts of the world as well.

Supplementary Materials: The following are available online at https:/ /www.mdpi.com/article/ 10.3390/pathogens10070871/s1, Supplement 1: Questionnaire, Figure S1: Correlation of the heterotrophic plate counts (HPC) of bacteria and the TOC results of water samples derived from bottled water dispensers placed in medical institutions, Figure S2: Tendencies of counts of heterotrophic plate counts (HPC) of bacteria and filamentous fungi in bottled water dispensers placed in medical institutions, as the water bottles expire, Figure S3: Correlation of the HPC at $22{ }^{\circ} \mathrm{C}$ and filamentous fungal counts ( $\mathrm{y}=-657.1 * \mathrm{x}+8679.3, p=0.02982, \mathrm{R}=-0.36)$ in bottled water dispensers placed in medical institutions, Figure S4: Heterotrophic plate counts (HPC) of bacteria and filamentous fungi in different sampling months of the bottled water dispensers placed in medical institutions, Figure S5: Heterotrophic plate counts (HPC) of bacteria in water samples collected from bottled water dispensers placed in distinct medical institutions, Figure S6: Filamentous fungi on drip tray and volume flow results of the water derived from bottled water dispensers in medical institutions $(y=0.1 * x+-1.1, p=0.00134, R=0.56)$, Table S1: Statistical description of numerical variables from the survey of bottled water dispensers in medical institutions, Table S2: Statistical description of measured numerical variables from the survey of bottled water dispensers in medical institutions. *: Subcomponent referred in the study. NA: Number of samples, for which data was not available, Table S3: Significant relationships of filamentous fungal concentrations in water samples [CFU/100 mL] derived from bottled water dispensers in medical institutions. a: logarithmized data, Table S4: Significant relationships of yeast concentration in water samples [CFU/100 mL] derived from bottled water dispensers in medical institutions. a: logarithmized data, Table S5: Significant relationships of fungi on drip trays of bottled water dispensers in medical institutions. a: logarithmized data, Table S6: Connections of fungal counts of swab samples collected from the taps of bottled water dispensers to other parameters in medical institutions. a: logarithmized data, *: subcomponent variables contributing to the mean variable (Total Fungi).

Author Contributions: Conceptualization, M.V. and D.M.; methodology, Á.S.; sampling procedure, R.S. and Z.T.; sample processing, R.S., Z.T., D.M. and C.D.; molecular analysis, L.K., Z.T. and H.A.; 
statistical analyses, R.S.; writing-original draft preparation, R.S. and Z.T.; writing-review and editing, M.V., Á.S., B.K. and D.M.; visualization, R.S.; supervision, D.M. and Z.T.; funding acquisition, B.K. All authors have read and agreed to the published version of the manuscript.

Funding: This research was supported by the Ministry of Innovation and Technology within the framework of the Thematic Excellence Programme 2020, Institutional Excellence Subprogramme (TKP2020-IKA-12).

Institutional Review Board Statement: Not applicable.

Informed Consent Statement: Not applicable.

Data Availability Statement: The data presented in this study are available in the Supplementary Materials.

Conflicts of Interest: The authors declare no conflict of interest.

\section{References}

1. WHO. Guidelines for Drinking-Water Quality: Fourth Edition Incorporating the First Addendum, 4th ed.; World Health Organization: Geneva, Switzerland, 2017.

2. European Council. Council Directive 98/83/Ec of 3 November 1998 on the Quality Of Water Intended For Human Consumption; Official Journal L 330; Publication Office of the European Union: Luxembourg, 1998; pp. 32-54. Available online: https: / / eur-lex.europa.eu/legal-content/EN/TXT/?uri=celex\%3A31998L0083 (accessed on 9 July 2021).

3. Babič, M.N.; Gunde-Cimerman, N.; Vargha, M.; Tischner, Z.; Magyar, D.; Veríssimo, C.; Sabino, R.; Viegas, C.; Meyer, W.; Brandão, J. Fungal contaminants in drinking water regulation? A tale of ecology, exposure, purification and clinical relevance. Int. J. Environ. Res. Public Health 2017, 14, 636. [CrossRef]

4. Ministry of Health. Government Decree 201/2001 on the Quality and Monitoring Requirements of Drinking Water, 1st ed.; Ministry of Health: Budapest, Hungary, 2001.

5. González, C.; Gutiérrez, C.; Grande, T. Bacterial flora in bottled uncarbonated mineral drinking water. Can. J. Microbiol. 1987, 33, 1120-1125. [CrossRef]

6. Bartram, J.; Cotruvo, J.; Exner, M.; Fricker, C.; Glasmacher, A. Heterotrophic plate counts and drinking-water safety: The significance of HPCs for water quality and human health. Water Intell. Online 2013, 12. [CrossRef]

7. European Federation of Bottled Waters (EFBW). Guide to Good Hygienic Practices for Packaged Water in Europe; Luxembourg, Brussels. 2012. Available online: https:/ / ec.europa.eu/food/system/files/2016-11/biosafety_fh_guidance_eu_guide_hygiene_ packaged_water_en.pdf (accessed on 9 July 2021).

8. Pierson, M.D. HACCP: Principles and Applications; Springer: Berlin/Heidelberg, Germany, 2012.

9. Tischner, Z.; Kredics, L.; Marik, T.; Vörös, K.; Kriszt, B.; Péter, B.; Magyar, N. Environmental characteristics and taxonomy of microscopic fungi isolated from washing machines. Fungal Biol. 2019, 123, 650-659. [CrossRef] [PubMed]

10. Zalar, P.; Novak, M.; De Hoog, G.S.; Gunde-Cimerman, N. Dishwashers-A man-made ecological niche accommodating human opportunistic fungal pathogens. Fungal Biol. 2011, 115, 997-1007. [CrossRef] [PubMed]

11. Zupančič, J.; Babič, M.N.; Zalar, P.; Gunde-Cimerman, N. The black yeast Exophiala dermatitidis and other selected opportunistic human fungal pathogens spread from dishwashers to kitchens. PLoS ONE 2016, 11, e0148166. [CrossRef] [PubMed]

12. Yamaguchi, M.U.; Rampazzo, R.D.C.P.; Yamada-Ogatta, S.F.; Nakamura, C.V.; Ueda-Nakamura, T.; Filho, B.P.D. Yeasts and filamentous fungi in bottled mineral water and tap water from municipal supplies. Braz. Arch. Biol. Technol. 2007, 50, 1-9. [CrossRef]

13. Cabral, D.; Pinto, V.E.F. Fungal spoilage of bottled mineral water. Int. J. Food Microbiol. 2002, 72, 73-76. [CrossRef]

14. Otterholt, E.; Charnock, C. Microbial quality and nutritional aspects of Norwegian brand waters. Int. J. Food Microbiol. 2011, 144, 455-463. [CrossRef]

15. Ameen, F.; Albejad, A.; Gashgari, R.; Murialdo, S.; Al-Sabri, A.; Albejad, H. Diversity of fungi in bottled water in Jeddah, Saudi Arabia. Water Supply 2017, 18, 1664-1673. [CrossRef]

16. Da Silva, P.R.; De Mesquita, A.R.C.; De Lima, M.A.B.; Pires, E.F. Fungi in bottled water. J. Environ. Anal. Prog. 2018, 3, 410-416. [CrossRef]

17. Muittari, A.; Kuusisto, P.; Virtanen, P.; Sovijärvi, A.; Grönroos, P.; Harmoinen, A.; Antila, P.; Kellomäki, L. An epidemic of ex-trinsic allergic alveolitis caused by tap water. Clin. Allergy 1980, 10, 77-90. [CrossRef]

18. Niemi, R.M.; Knuth, S.; Lundström, K. Actinomycetes and fungi in surface waters and in potable water. Appl. Environ. Microbiol. 1982, 43, 378-388. [CrossRef]

19. Antoniadou, A. Outbreaks of zygomycosis in hospitals. Clin. Microbiol. Infect. 2009, 15, 55-59. [CrossRef]

20. Hageskal, G.; Lima, N.; Skaar, I. The study of fungi in drinking water. Mycol. Res. 2009, 113, 165-172. [CrossRef] [PubMed]

21. Caggiano, G.; Diella, G.; Triggiano, F.; Bartolomeo, N.; Apollonio, F.; Campanale, C.; Lopuzzo, M.; Montagna, M.T. Occurrence of fungi in the potable water of hospitals: A public health threat. Pathogens 2020, 9, 783. [CrossRef] [PubMed] 
22. Perdomo, H.; Sutton, D.A.; Garcia, D.; Fothergill, A.W.; Cano-Lira, J.F.; Gene, J.; Summerbell, R.C.; Rinaldi, M.G.; Guarro, J. Spectrum of clinically relevant Acremonium species in the United States. J. Clin. Microbiol. 2010, 49, 243-256. [CrossRef]

23. Jurjevic, Z.; Peterson, S.W.; Horn, B.W. Aspergillus section Versicolores: Nine new species and multilocus DNA sequence based phylogeny. IMA Fungus 2012, 3, 59-79. [CrossRef]

24. Harrington, T.C.; McNew, D.; Steimel, J.; Hofstra, D.; Farrell, R. Phylogeny and taxonomy of the Ophiostoma piceae complex and the Dutch elm disease fungi. Mycologia 2001, 93, 111-136. [CrossRef]

25. Vu, D.; Groenewald, M.; Szöke, S.; Cardinali, G.; Eberhardt, U.; Stielow, B.; de Vries, M.; Verkleij, G.; Crous, P.; Boekhout, T.; et al. DNA barcoding analysis of more than 9000 yeast isolates contributes to quantitative thresholds for yeast species and genera delimitation. Stud. Mycol. 2016, 85, 91-105. [CrossRef]

26. Zalar, P.; de Hoog, G.; Schroers, H.-J.; Crous, P.; Groenewald, J.; Gunde-Cimerman, N. Phylogeny and ecology of the ubiquitous saprobe Cladosporium sphaerospermum, with descriptions of seven new species from hypersaline environments. Stud. Mycol. 2007, 58, 157-183. [CrossRef]

27. Scorzetti, G.; Fell, J.W.; Fonseca, A.; Statzell-Tallman, A. Systematics of basidiomycetous yeasts: A comparison of large subunit D1/D2 and internal transcribed spacer rDNA regions. FEMS Yeast Res. 2002, 2, 495-517. [CrossRef]

28. Aveskamp, M.M.; de Gruyter, J.; Woudenberg, J.H.C.; Verkley, G.J.M.; Crous, P.W. Highlights of the Didymellaceae: A polyphasic approach to characterise Phoma and related pleosporalean genera. Stud. Mycol. 2010, 65, 1-60. [CrossRef]

29. De Hoog, G.; Vicente, V.; Najafzadeh, M.J.; Harrak, M.; Badali, H.; Seyedmousavi, S. Waterborne Exophiala species causing disease in cold-blooded animals. Pers. Mol. Phylogeny Evol. Fungi 2011, 27, 46-72. [CrossRef] [PubMed]

30. Prenafeta-Boldu, F.X.; Summerbell, R.; De Hoog, G.S. Fungi growing on aromatic hydrocarbons: Biotechnology's unexpected encounter with biohazard? FEMS Microbiol. Rev. 2006, 30, 109-130. [CrossRef]

31. Schroers, H.-J.; O’Donnell, K.; Lamprecht, S.C.; Kammeyer, P.L.; Johnson, S.; Sutton, D.A.; Rinaldi, M.G.; Geiser, D.M.; Summerbell, R.C. Taxonomy and phylogeny of the Fusarium dimerum species group. Mycologia 2009, 101, 44-70. [CrossRef] [PubMed]

32. Kiyuna, T.; An, K.-D.; Kigawa, R.; Sano, C.; Miura, S.; Sugiyama, J. Molecular assessment of fungi in "black spots" that deface murals in the Takamatsuzuka and Kitora Tumuli in Japan: Acremonium sect. Gliomastix including Acremonium tumulicola sp. nov. and Acremonium felinum comb. nov. Mycoscience 2011, 52, 1-17. [CrossRef]

33. Houbraken, J.; Frisvad, J.; Seifert, K.A.; Overy, D.P.; Tuthill, D.M.; Valdez, J.G.; Samson, R. New penicillin-producing Penicillium species and an overview of section Chrysogena. Pers. Mol. Phylogeny Evol. Fungi 2012, 29, 78-100. [CrossRef] [PubMed]

34. Nonaka, K.; Kaifuchi, S.; Ōmura, S.; Masuma, R. Five new Simplicillium species (Cordycipitaceae) from soils in Tokyo, Japan. Mycoscience 2013, 54, 42-53. [CrossRef]

35. Pinto, M.; Langer, T.M.; Hüffer, T.; Hofmann, T.; Herndl, G.J. The composition of bacterial communities associated with plastic biofilms differs between different polymers and stages of biofilm succession. PLoS ONE 2019, 14, e0217165. [CrossRef]

36. Gaitán, A.C.R.; Moret, A.; Hontangas, J.L.L.; Molina, J.M.; López, A.I.A.; Cabezas, A.H.; Maseres, J.M.; Arcas, R.C.; Ruiz, M.D.G.; Chiveli, M.Á.; et al. Nosocomial fungemia by Candida auris: First four reported cases in continental Europe. Rev. Iberoam. Micol. 2017, 34, 23-27. [CrossRef]

37. Tian, S.; Rong, C.; Nian, H.; Li, F.; Chu, Y.; Cheng, S.; Shang, H. First cases and risk factors of super yeast Candida auris infection or colonization from Shenyang, China. Emerg. Microbes Infect. 2018, 7, 1-9. [CrossRef]

38. Kojic, E.M.; Darouiche, R.O. Candida infections of medical devices. Clin. Microbiol. Rev. 2004, 17, 255-267. [CrossRef]

39. Horton, M.V.; Nett, J.E. Candida auris infection and biofilm formation: Going beyond the surface. Curr. Clin. Microbiol. Rep. 2020, 7, 51-56. [CrossRef]

40. Tischner, Z.; Kredics, L.; Vargha, M.; Sebestyén, Á.; Marik, T.; Vörös, K.; Magyar, D. A háztartási vizes berendezésekben előforduló gombák egészségügyi vonatkozásai. AMEGA 2017, 24, 13-18.

41. Mille-Lindblom, C.; Fischer, H.; Tranvik, L.J. Antagonism between bacteria and fungi: Substrate competition and a possible tradeoff between fungal growth and tolerance towards bacteria. Oikos 2006, 113, 233-242. [CrossRef]

42. Magyar, D.; Stefán, G.; Körmöczi, P.; Kredics, L.; Varró, M.J.; Balogh, K.; Nékám, K. Species composition of indoor fungi in Hungary. Egészségtudomány 2017, 60, 13-37.

43. Páldy, A.; Bobvos, J.; Málnási, T. The impact of climate change on human health and health care system in Hungary [with English abstract]. Magy. Tudomány 2018, 179, 1336-1348.

44. Magyar, D.; Vass, M.; Li, D.-W. Dispersal Strategies of Microfungi. In Fungal Biology; Springer: Berlin/Heidelberg, Germany, 2016; pp. 315-371.

45. Peñalva, M.A.; Arst, H.N. Regulation of gene expression by ambient pH in filamentous fungi and yeasts. Microbiol. Mol. Biol. Rev. 2002, 66, 426-446. [CrossRef]

46. Silvestrini, M.C.; Galeotti, C.L.; Gervais, M.; Schininà, E.; Barra, D.; Bossa, F.; Brunori, M. Nitrite reductase from Pseudomonas aeruginosa: Sequence of the gene and the protein. FEBS Lett. 1989, 254, 33-38. [CrossRef]

47. Kurtzman, C.; Fell, J.W.; Boekhout, T. The Yeasts: A Taxonomic Study, 5th ed.; Elsevier BV: Amsterdam, The Netherlands, 2011.

48. Tintelnot, K.; De Hoog, G.S.; Thomas, E.; Steudel, W.I.; Huebner, K.; Seeliger, H.P.R. Cerebral phaeohyphomycosis caused by an Exophiala species. Mycoses 1991, 34, 239-244. [CrossRef] [PubMed]

49. De Hoog, G.; Matsumoto, T.; Matsuda, T.; Uijthof, J. Exophiala jeanselmei var. lecanii-corni, an aetiologic agent of human phaeohyphomycosis, with report of a case. Med. Mycol. 1994, 32, 373-380. [CrossRef] [PubMed] 
50. Tiedje, J.M. Ecology of denitrification and dissimilatory nitrate reduction to ammonium. In Environmental Microbiology of Anaerobes; John Wiley and Sons: New York, NY, USA, 1988; pp. 179-244.

51. Ariole, C.N.; Ofuase, N. Anaerobic denitrification and biotechnological potentials of filamentous fungi isolated from coastal marine sediment. Int. J. Microbiol. Mycol. 2016, 4, 8-15.

52. Han, Y.W.; Cheeke, P.R.; Anderson, A.W.; Lekprayoon, C. Growth of Aureobasidium pullulans on straw hydrolysate. Appl. Environ. Microbiol. 1976, 32, 799-802. [CrossRef]

53. Borneman, A.R.; Zeppel, R.; Chambers, P.J.; Curtin, C.D. Insights into the Dekkera bruxellensis genomic landscape: Comparative genomics reveals variations in ploidy and nutrient utilisation potential amongst wine isolates. PLoS Genet. 2014, 10, e1004161. [CrossRef]

54. Leber, A.L. Clinical Microbiology Procedures Handbook, 4th ed.; American Society for Microbiology: Washington, DC, USA, 2016.

55. Barathikannan, K.; Khusro, A.; Agastian, P. Isolation and molecular characterization of xylitol producing wild yeast strains from different fermented fruit juices. South Indian J. Biol. Sci. 2016, 2, 415. [CrossRef]

56. Guerrero, M.G.; Gutierrez, M. Purification and properties of the NAD(P)H:nitrate reductase of the yeast Rhodotorula glutinis. Biochim. Biophys. Acta BBA Enzym. 1977, 482, 272-285. [CrossRef]

57. Tachiki, T.; Sakai, K.; Yamamoto, K.; Hatanaka, M.; Tochikura, T. Conversion of nitrite to nitrate by nitrite-resistant yeasts. Agric. Biol. Chem. 1988, 52, 1999-2005. [CrossRef]

58. Robertson, E.J.; Wolf, J.M.; Casadevall, A. EDTA inhibits biofilm formation, extracellular vesicular secretion, and shedding of the capsular polysaccharide glucuronoxylomannan by Cryptococcus neoformans. Appl. Environ. Microbiol. 2012, 78, 7977-7984. [CrossRef] [PubMed]

59. Cruz, L.F.; Cobine, P.A.; De La Fuente, L. Calcium increases surface attachment, biofilm formation, and twitching motility in Xylella fastidiosa. Appl. Environ. Microbiol. 2012, 78, 1321-1331. [CrossRef] [PubMed]

60. Smit, G.; Logman, T.J.; E Boerrigter, M.; Kijne, J.W.; Lugtenberg, B.J. Purification and partial characterization of the Rhizobium leguminosarum biovar viciae $\mathrm{Ca}^{2+}$-dependent adhesin, which mediates the first step in attachment of cells of the family Rhizobiaceae to plant root hair tips. J. Bacteriol. 1989, 171, 4054-4062. [CrossRef]

61. Patrauchan, M.A.; Sarkisova, S.; Sauer, K.; Franklin, M.J. Calcium influences cellular and extracellular product formation during biofilm-associated growth of a marine Pseudoalteromonas sp. Microbiology 2005, 151, 2885-2897. [CrossRef]

62. Patrauchan, M.A.; Sarkisova, S.A.; Franklin, M.J. Strain-specific proteome responses of Pseudomonas aeruginosa to biofilmassociated growth and to calcium. Microbiology 2007, 153, 3838-3851. [CrossRef]

63. Cai, W.; De La Fuente, L.; Arias, C.R. Biofilm formation by the fish pathogen Flavobacterium columnare: Development and parameters affecting surface attachment. Appl. Environ. Microbiol. 2013, 79, 5633-5642. [CrossRef]

64. Martínez-Gil, M.; Romero, D.; Kolter, R.; Espinosa-Urgel, M. Calcium causes multimerization of the large adhesin LapF and modulates biofilm formation by Pseudomonas putida. J. Bacteriol. 2012, 194, 6782-6789. [CrossRef]

65. Hijnen, W.A.M.; Schultz, F.; Harmsen, D.J.H.; Brouwer-Hanzens, A.H.; van der Wielen, P.; Cornelissen, E.R. Calcium removal by softening of water affects biofilm formation on PVC, glass and membrane surfaces. Water Supply 2016, 16, 888-895. [CrossRef]

66. Júnior, M.C.; Arantes, A.D.M.; Silva, H.M.; Costa, C.R.; Silva, M.D.R.R. Acremonium kiliense: Case report and review of published studies. Mycopathologia 2013, 176, 417-421. [CrossRef] [PubMed]

67. Zeng, J.S.; Sutton, D.A.; Fothergill, A.W.; Rinaldi, M.G.; Harrak, M.J.; de Hoog, G.S. Spectrum of clinically relevant Exophiala species in the United States. J. Clin. Microbiol. 2007, 45, 3713-3720. [CrossRef] [PubMed]

68. De Hoog, G.S.; Zeng, J.S.; Harrak, M.J.; Sutton, D.A. Exophiala xenobiotica sp. nov., an opportunistic black yeast inhabiting environments rich in hydrocarbons. Anton. Leeuw. Int. J. G. 2006, 90, 25-268. [CrossRef] [PubMed]

69. Najafzadeh, M.J.; Suh, M.K.; Lee, M.H.; Ha, G.Y.; Kim, J.R.; Kim, T.H.; Lee, H.J.; Choi, J.S.; Meis, J.; De Hoog, G.S. Subcutaneous phaeohyphomycosis caused by Exophiala equina, with susceptibility to eight antifungal drugs. J. Med Microbiol. 2013, 62, 797-800. [CrossRef]

70. Pfaller, M.A.; Diekema, D.; Mendez, M.; Kibbler, C.; Erzsebet, P.; Chang, S.-C.; Gibbs, D.L.; Newell, V.A.; The Global Antifungal Surveillance Group. Candida guilliermondii, an opportunistic fungal pathogen with decreased susceptibility to fluconazole: Geographic and temporal trends from the ARTEMIS DISK antifungal surveillance program. J. Clin. Microbiol. 2006, 44, 3551-3556. [CrossRef]

71. Pasqualotto, A.C.; Antunes, A.G.V.; Severo, L.C. Candida guilliermondii as the aetiology of candidosis. Rev. Do Inst. Med. Trop. São Paulo 2006, 48, 123-127. [CrossRef] [PubMed]

72. Babič, M.N.; Zalar, P.; Ženko, B.; Schroers, H.-J.; Džeroski, S.; Gunde-Cimerman, N. Candida and Fusarium species known as opportunistic human pathogens from customer-accessible parts of residential washing machines. Fungal Biol. 2015, 119, 95-113. [CrossRef] [PubMed]

73. Siqueira, J.; Sutton, D.A.; García, D.; Gené, J.; Thomson, P.; Wiederhold, N.; Guarro, J. Species diversity of Aspergillus section Versicolores in clinical samples and antifungal susceptibility. Fungal Biol. 2016, 120, 1458-1467. [CrossRef]

74. Guevara-Suarez, M.; Sutton, D.A.; Cano-Lira, J.F.; García, D.; Martin-Vicente, A.; Wiederhold, N.; Guarro, J.; Gené, J. Identification and antifungal susceptibility of Penicillium-like fungi from clinical samples in the United States. J. Clin. Microbiol. 2016, 54, 2155-2161. [CrossRef]

75. Sandoval-Denis, M.; Sutton, D.A.; Martin-Vicente, A.; Cano-Lira, J.F.; Wiederhold, N.; Guarro, J.; Gené, J. Cladosporium species recovered from clinical samples in the United States. J. Clin. Microbiol. 2015, 53, 2990-3000. [CrossRef] 
76. MSZ EN ISO 8199:2005. Water Quality—General Requirements and Guidance for Microbiological Examinations by Culture, “Vizminőség. Általános Útmutatás a Mikroorganizmusok Megszámlálására Tenyésztéssel"; Magyar Szabványügyi Testület: Budapest, Hungary, 2008.

77. MSZ EN ISO 16266:2006. Water Quality—Detection and Enumeration of Pseudomonas aeruginosa-Method by Membrane Filtration, “Vizminőség. Pseudomonas Aeruginosa Kimutatása és Megszámlálása. Membránszúréses Módszer"; Magyar Szabványügyi Testület: Budapest, Hungary, 2008.

78. White, T.J.; Bruns, T.; Lee, S.; Taylor, J. Amplification and direct sequencing of fungal ribosomal RNA genes for phylogenetics. In PCR Protocols, a Guide to Methods and Applications; Innis, M.A., Gelfand, D.H., Sninsky, J.J., White, T.J., Eds.; Academic Press: New York, NY, USA, 1990; pp. 315-322.

79. Liu, D. Molecular Detection of Human Fungal Pathogens, 1st ed.; CRC Press: Boca Raton, FL, USA, 2011; pp. 17-18. [CrossRef]

80. Hatvani, L.; Antal, Z.; Manczinger, L.; Szekeres, A.; Druzhinina, I.S.; Kubicek, C.P.; Nagy, A.; Nagy, E.; Vágvölgyi, C.; Kredics, L. Green mold diseases of Agaricus and Pleurotus spp. are caused by related but phylogenetically different Trichoderma species. Phytopathology 2007, 97, 532-537. [CrossRef] [PubMed]

81. Altschul, S.F.; Gish, W.; Miller, W.; Myers, E.W.; Lipman, D.J. Basic local alignment search tool. J. Mol. Biol. 1990, 215 , 403-410. [CrossRef]

82. Kosár, P. Microbiological and Chemical Safety of Drinking Water Derived from Bottled Water Dispenser. Bachelor's Thesis, Budapest University of Technology and Economics, Budapest, Hungary, 2014. (In Hungarian). 